\title{
BULLYING AND ADJUSTMENT PROBLEMS IN ISLAMIC ELEMENTARY SCHOOL
}

\author{
ERNI AGUSTINA SETIOWATI ${ }^{1}$ \\ Universitas Islam Sultan Agung Semarang
}

\section{Abstract}

The number of bullying cases is getting more significant among students. The effect of bullying covers some conditions of psychology, physic, and adjustment either for bullies, bully-victims or whoever witnesses the action (bystander). The cases of bullying more problematic if the action occurs in Islamic based schools. In the Holy Quran, there are 12 verses which correlate to enmity (i'tada ya'tadi). Besides, it also has 39 verses about scolding (istabzaa yastahziu). Thus, actions relating to harassment should be decreased more than non-Islamic based schools. This study aims to describe bullying behavior and adjustment. The quantitative method is used for this study. The sample involved in this study was 73 students of Islamic elementary schools in the district of Semarang Utara selected by purposive sampling. The data were collected through a questionnaire of bullying behavior, reliability coefficient $\alpha=0.890$ and corrected correlation coefficients was in the range between 0.268-0.552. SCT (Sentence Completion Test) for Children was used to measure perception of adjustment problems. Data analyzed by a descriptive statistic. The finding indicated that bullying was in a high category and students have some adjustment problems related to interpersonal relationship, in school and family, and self-concept.

Kasus bullying akhir-akhir ini terus meningkat di kalangan siswa. Dampak dari bullying antara lain berpengaruh pada kondisi psi-

Corresponding author; email: ${ }^{1}$ erniagustina@unissula.ac.id

ISSN 0852-7172 (p) 2461-064X (e)

(C) 2017 Walisongo: Jurnal Penelitian Sosial Keagamaan

http://journal.walisongo.ac.id/index.php/walisongo 
kologis, fisik, dan penyesuaian baik bagi pelaku, korban, maupun teman korban atau siapapun yang menyaksikan kejadian tersebut. Kasus bullying ini lebih problematik bila terjadi di sekolah berbasis agama Islam. Dalam al-Quran terdapat 12 ayat yang berkaitan dengan kata permusuhan (i'tada ya'tadi). Disamping itu, terdapat 39 ayat mengenai cacian (ihtahzaa yastahziu). Sehingga semestinya kejadian yang berkaitan dengan kekerasan dapat ditekan dibanding pada sekolah umum. Penelitian ini bertujuan untuk mendeskripsikan perilaku bullying dan masalab penyesuaian. Sampel yang dilibatkan dalam penelitian ini adalab 73 siswa dari sekolah dasar islam di kota semarang yang dipilih menggunakan cara purposive sampling. Pengumpulan data menggunakan kuesioner perilaku bullying, reliabilitas $\alpha=0.890$ dan koefisien korelasi antara skor aitem-total bergerak antara 0.268-0.552. SCT (Sentence Completion Test) untuk anak digunakan untuk mengukur persepsi terhadap masalah penyesuaian. Data dianalisis menggunakan statistik deskriptif. Hasil penelitian menunjukkan babwa perilaku bullying pada siswa tergolong pada kategori tinggi dan terdapat beberapa masalah penyesuaian yang terkait dengan relasi interpersonal, penyesuaian di sekolah dan keluarga dan masalah konsep diri.

Keywords: bullying; adjustment problem; Islamic school.

\section{Introduction}

The success of students to adjust to their school environment is one of the factors that contribute to their achievement. The ability to change the internal and external conditions in order to align with the needs of selves is important to be owned by them in order to optimize the resources possessed. It is given that stressor at the school or environment of children either in terms of relationships with peers or families is increasingly diverse.

Stressors experienced by children both as a student at the school and family member at home and community members 
around the house affect how they perceive the environmental conditions and the quality of the adjustment. As usual in the process of perceiving, a good experience will result in a positive perception in children, and vice versa a bad experience will bring a bad perception of the situation in the environment. Both good and bad perceptions of the children about the adjustment to existing environment will form behavior pattern of certain adjustment.

There are two terms dealing with the relationship between individuals and their environment. Siswanto $(2007,34-35)$ stated that when someone changes his self in order to match his environment, it is called adaptation. This definition emphasizes more on changes individuals do for their selves in order to be able to match their environment. While adjustment is individuals' effort to change the environment in order to match them. Individuals who are psychologically health will be able to do both equally. While Gerungan (2004, 59-60) defined adjustment as an effort to change one's self in order to match environment or what-socalled alloplastic adjustment and change environment in order to match one's self which is then called alloplastic adjustment.

According to Hurlock, the adjustment is the ability of individuals to show the livable attitude and behavior, so they can be accepted by the group or the environment by following the norms and regulations. Kondisi yang diperlukan untuk mencapai penyesuaian diri yang baik yaitu dengan cara bimbingan untuk membantu anak belajar menjadi realistis tentang diri dan kemampuannya, serta bimbingan untuk belajar bersikap bagaimana cara yang akan membantu penerimaan sosial dan kasih sayang dari orang lain. The conditions needed to achieve a good adjustment are through guidance to help children learn to be realistic about themselves and their abilities, as well as guidance to learn how to act accordingly for the social acceptance and affection from others. 
The optimal condition for children to develop their maximum potential is a conducive environment that can bring stress in the form of eustress and distress within certain limits. However, there is often a stressor that appears strong enough to cause an imbalance in self. One stressor that is often experienced by students both at school and outside the school environment is bullying.

To get comfort and safety in the school environment is one of the basic needs of students. This is in accordance with the theory of human motivation by Abraham Maslow who stated that security is a basic requirement that must be met in order to aim for self-actualization. The protection for security has definitely been enshrined the law for the protection of children 23, 2002 article 54 which states: "kids at home and school environment must be protected from acts of violence committed by teachers, school administrators or friends at related school, or other educational institution".

In fact, a sense of security and comfort is difficult to obtain when every element at school is less support each other to create harmony in a good life for academic and self-competence development either in the emotional or social side. As a result, students then learn within the unfavorable situation. One of the issues arising nowadays is a violence committed repeatedly or bullying by other students who often do because of seniority, to feel superior, and feel they have the authority. In addition, such repeated violence is even carried out by the teacher.

Bullying according to Sharp and Smith $(2003,1)$ is a form of aggressive behavior which is hurtful and deliberate, sometimes persistent continuing for weeks, months, or even years. It is difficult for someone being bullied to defend themselves. Bullying takes many forms and it can be physical such as hitting, kicking, taking or damaging of belongings; verbal such as name-calling, 
insulting, repeated teasing, racist remarks; and indirect such as spreading any rumors, excluding someone from the social group. For most students, bullying happened in and around school environment and the play ground, the most common location.

The results of the survey in Semarang conducted by Siswati and Widayanti $(2009,1)$ indicated that $37.55 \%$ of the 78 students surveyed were bully-victims, as many as $42.5 \%$ dari korban mengalami bullying secara fisik dan 34, $06 \%$ mengalami bullying non fisik. of victims experienced physical bullying and $34.06 \%$ had non-physical bullying. Lebih lanjut, penelitian yang dilakukan oleh Yayasan Semai Jiwa Amini pada tahun 2008 (Wiyani, 2012) mengenai bullying di tiga kota besar di Indonesia, yakni Yogyakarta, Surabaya, dan Jakarta. The effect of becoming bully-victims is varied and long-term either academically in school, emotionally, or socially. Goddard $(2007,5)$ argued that bullying have many destructive impacts. Furthermore, Sharp and Smith $(2003,2)$ stated that bully-victims can suffer pain, refuse to go to school, lost self-confidence and self-esteem, blame themselves causing to get bullying. Feeling unpleased or unhappy at school can affect their concentration and study. Many of them then feel symptoms related to stress such as stomachache, headache, bad dream, and anxiety. Besides, they avoid to go to school and do not want to leave their home. Coloroso (2003) memberi pengertian bahwa bullying merupakan tindakan intimidasi yang dilakukan pihak yang lebih kuat terhadap pihak yang lebih lemah. The study which was conducted by Glew, Fan, Katon, Rivara, and Kernic (2005, 1030)concerns about bullying and its role in school violence, depression, and health concerns have grown. However, no large studies in the United States have examined the prevalence of bullying during elementary school or its association with objective measures of school attendance and achievement. OBJECTIVE To deter- 
mine the prevalence of bullying during elementary school and its association with school attendance, academic achievement, disciplinary actions, and self-reported feelings of sadness, safety, and belonging. DESIGN Cross-sectional study using 2001-2002 school data. SETTING Urban, West Coast public school district. PARTICIPANTS Three thousand five hundred thirty $191.4 \%$ on 3530 elementary students of 3, 4, and 5 graders in America showed that bully-victims have the lower achievement, feeling unsafe, having no sense of belonging to the school, and feeling sad. So, this bullying experience becomes a serious problem in elementary school.

Furthermore, O'Moore and Minton $(2004,8)$ revealed that the form of bullying behavior is also determined by gender. In men, the bullying behavior is more frequently in the form of physical and verbal, such as hitting, pushing during a fight, and mocking with particular calls. While women are more likely to be verbal and relationship, such becoming the object of gossip, not included in social relations, and ridiculed. Bullying behavior that is open and repeated over time will lead to negative behavior both for the offender, the victim, and anyone else seeing it.

Bullying has a major impact on the development of the students both socially and academically. Based on research conducted by Dwipayanti and Indrawati $(2014,251)$ to the elementary school students in Badung, Gianyar and Denpasar, it was found that children as the victims of bullying have difficulty in associating, they are afraid to come to school so that the level of absence is high, having left behind in the lesson, and hard in concentration, so it has impact on learning achievement. Besides, bullying also has psychological impact significantly. This is in line with the study which was conducted by Hunter, Boyle, and Warden $(2007,806)$ on 1429 students aged 8 to 13 years in Scotland, the fact that students who become bully-victims show 
depression syndrome more. Furthermore, the study conducted by Septrina et al. (2009) found that bullying has a significant relationship with self-esteem.

In another side, besides bullying has an impact on students' adjustment, it also has an impact on school bonding which has an important role in adjustment that finally has an impact on academic performance. The study which was conducted by Simons-Morton, Crumps, Haynieand Saylor $(1999,99)$ on 6-8 graders in America, found a fact that student-school bonding has a positive correlation with adjustment at school, view at school climate, and behavioral problems such as disobeying regulation and anti-social. While the study which was conducted by Raju and Rahamtulla $(2007,78)$ in India on 9 and 10 graders about adjustment problems found that students' adjustment problems at school are affected by school variables such as class atmosphere, learning place, provided learning media, and class management type, gender, as well as education and parents' occupation. Furthermore, the study was conducted by Bottiani, Bradshaw, and Mendelson (2016) found that adjustment problems lead to a risk of out-of-school suspension.

Bullying selain ditemui di sekolah umum juga tidak jarang dijumpai di sekolah-sekolah berbasis agama seperti sekolah Islam. Bullying, besides encountered in public schools, is also common in religious based school like Islamic school that promotes Islamic values. Nilai-nilai Islam sudah mulai dari dini diajarkan seperti misalnya di TK Islam, hadist yang pertama kali dikenalkan pada anak adalah “ La Tagdhob ...” yang artinya “Jangan marah ...”.Islamic values have already been initiated early in Islamic kindergarten school. The first hadith to be introduced to the children is "la taghdhab" which means "Do not be angry". Penanaman karakter pada siswa SD Islam yang berdasarkan pada nilai-nilai Islam juga secara kontinyu dilaku- 
kan. The character building in Islamic elementary school students based on the Islamic values is continuously performed. Development and formation of character according to Islam as stated by Majid \& Andayani (see Aeni 2014, 57) on children aged 7-8 years are responsibility phase, where they are educated to responsible for their obligations when they reach 9-10 years old, it is a caring phase. During this phase, caring for physical environment and empathy to others must be developed in the classroom process. So that, if this phase is conducted as an effort of character formation, bullying behavior, therefore, should be decreased.Berdasarkan paparan di atas penulis tertarik untuk mengetahui masalah penyesuaian individual siswa di SD Islam. But in fact, based on the preliminary study which conducted by observation and interview method of collecting data, there are many un-empathic ways in students relationship in elementary school.

Based on the above explanation, the researcher is interested in finding out the individual adjustment problems and bullying in Islamic elementary school students. The outcome of problems profiling can serve as a guide for developing prevention and intervention programs in school.

\section{Method}

This study involved 73 students of Islamic elementary schools in the district of Semarang Utara as a sample. The sample in this study was selected purposively. The data were collected through a questionnaire of bullying behavior and Sentence Completion Test for children. Bullying behavior questioner is a self-report measurement type, consisted of 39 items, and assess bullying verbally, physically, and indirectly.

The try out on the scale of bullying was administered to 260 students of 4 and 5 graders in six elementary schools in Sema- 
rang Utara. The validity test on the items used product moment correlation from Pearson, while the reliability test used Alpha Cronbach test. The result of the item validity test on the scale obtained 22 items with high correlation coefficient $r_{i x} \geq 0,250$ while 17 items with low correlation coefficient $r_{\text {ix }} 0,250$, with the correlation coefficient, ranged between 0,268-0,552, reliability $\alpha=0,890$. We conclude that questionnaire of bullying behavior is acceptable as a measurement instrument for this research.

The second instrument is sentence completion test for children consist of 56 items. Sentence Completion Test is a widespread tool for assessing adjustment problems in children. Students receive a set of the incomplete sentence and they fill up. The domain of adjustment assessed by this instrument is self-concept adjustment, family adjustment, interpersonal relationship adjustment, and school adjustment. The problem of adjustment can be known through scoring with these following guidance: (1) score 0 refers to normal or no disturbance, (2) score 1 refers to mild disturbance, subject need little guidance from adult, (3) score 2 refers to very disturbed adjustment so that he needs treatment adequately.

The data analysis in this study was conducted through descriptive statistical analysis.

\section{Result}

Based on the analysis result on the instrument of SCT for children, it is found that almost a half of the 73 respondents got the problem in individual adjustment. Most of them reported adjustment problem in self-concept, wherein the instrument of Sentence Completion Test measured in the item numbers: 2, 7, $17,23,27,28,44,47,50,51$, and 55. Besides, some of them had family adjustment problem which was disclosed through the item numbers 11,35 , and 48 , the adjustment problem on in- 
terpersonal relationship found problematic seemed through the item numbers 14 and 20, while the school adjustment problem was mainly disclosed through the item numbers 12 and 45 . Below is the detail problems experienced by the respondents as on the figure 1.

Figure 1

The profile of individual adjustment problems

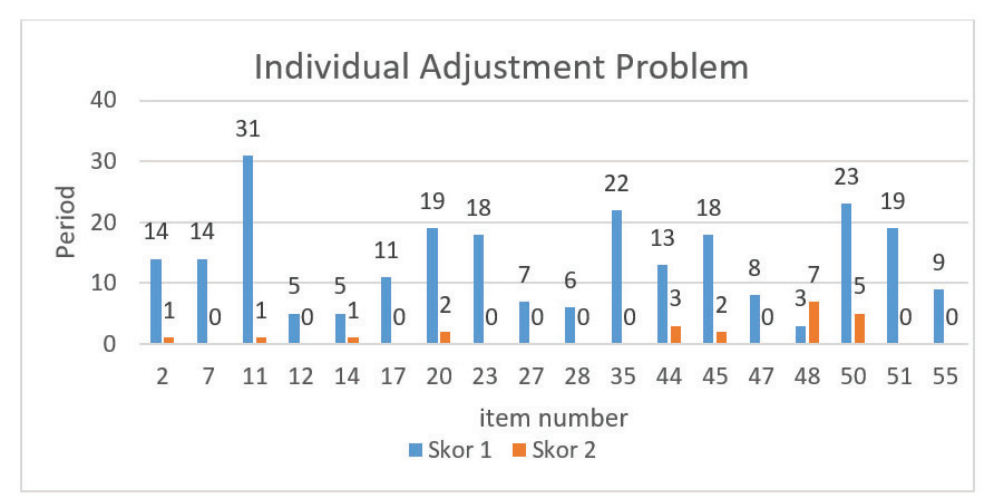

Table 1

The description of adjustment problems

\begin{tabular}{llc}
\hline \multicolumn{1}{c}{ Kinds of Problem } & \multicolumn{1}{c}{ Level } & Percentage \\
\hline \multirow{2}{*}{ Self-Concept Adjustment } & Mild Disturbance & $34 \%$ \\
& Severe Disturbed & $9 \%$ \\
Family Adjustment & Mild Disturbance & $48 \%$ \\
& Severe Disturbed & $9 \%$ \\
Interpersonal Relationship & Mild Disturbance & $26 \%$ \\
Adjustment & Severe Disturbed & $5 \%$ \\
\multirow{2}{*}{ School Adjustment } & Mild Disturbance & $29 \%$ \\
& Severe Disturbed & $1,30 \%$ \\
\hline
\end{tabular}

The bullying behavior measured by a questionnaire of bullying on 73 respondents. The choice of answers for them were 3 , namely, score 1 , score 2 , and score 3 . Based on the data 
analysis result, it is known that the respondents in this study conducted nonverbal bullying behaviour such as hitting, pushing, pinching, bullying, and verbal bullying such as insulting, scorning, snapping, scolding without any clear reason, denouncing, and mocking, as well as indirect bullying such as keeping distance, not willing to invite in playing in a group, avoiding, etc.

\section{Analysis and Discussion}

Based on the finding of this study, it is known that individual adjustment on the respondents indicated to have some problems in 4 areas of adjustment such as family adjustment, school adjustment, and adjustment on the interpersonal relationships. These problems faced by the students could affect other problems in school, such as bullying problem which described one of the effects of poor individual adjustment.

Furthermore, the finding showed that students have family adjustment problem. It is found a fact that perception on a figure of the mother had a serious problem so that it needed to get professional help. The perception of a figure of the bad mother was perceived by 7 among 73 respondents (10\%). Then, the perception of a figure of the father also showed problem disturbing the respondents so that it needed to be directed in order that they could solve it. This perception of a figure of the father was the most problem reported by respondents compared to other areas, where 31 of 73 respondents or $42,5 \%$. This is an overview of the general problem faced by the students of the elementary school where the problem still deals with their families. Wenar and Kerig $(2000,48)$ stated that children who get harshed will respond to their friends in a parallel way with behavior showed by their parents. For example, they will be a lack of sympathetic response and care when they know their friends 
having problems compared to their other friends, and they will react more such as feeling fear and doing aggression physically. This is in line with the study which was conducted by Espelage, Bosworth, and Simon $(2000,326)$ that parents implementing discipline physically, spending time without adult's monitor, the negative effect of coeval friends, and care about neighborhood safety (neighborhood safety concerns) have a positive correlation with bullying behavior. Sharp and Smith $(2003,4)$ stated that children who are bullied at home or seen their parents or siblings bullying others tend to exhibit a similar way to behave they friends at school. Inappropriate treatment (maltreated) on children, mainly child abuse according to the integrative model proposed by Wolfe (Wenar and Kerig 2000, 321) was caused by the condition where it is a lack of preparation to be parents, lack of control and ability in coping strategies, as well as stress conditions.

Based on the data analysis, it is known that the respondents had problems in self-concept adjustment. The problems among which were their view on unpleasure past events, feeling unable to do something and solve with a way which was not constructive, feeling anxious, guilty, spending spare time, feeling sad, perception on gender either male or female, bad things which had been done, ideal body image, and expression of anger. The developmental phase of elementary children grades 3-5, or aged between 8-11 years, as stated by Ormrod $(2008,321)$ is a period when they have desire repeatedly towards teachers' agreement or their friends and they have an improvement of their ability in reflecting their thought and self-motivation and others. While children grade 6-8 are suspected to begin the increase of bullying behavior.

It is found based on the data analysis that the respondents had a problem in interpersonal relational adjustment. The prob- 
lem they faced was related to their perception of the relations between teachers and students where they faced so far and among students. There was 1 respondent in this study who had a bad attitude and was problematic so that the student needed to get professional treatment with the figure of the teacher, while the 5 among 73 had a problem which could be solved through their teachers or parents. The respondents judged themselves less good among others. While dealing with the problem of adjusting to school, they reported having a problem with their adjustment in class and the problem with other students. There were $25 \%$ of them reported to have a problem with other students related to aggressive action physically, verbally, or psychologically that they experienced either it repeatedly happened which was concluded into bullying category and common harassment. This finding is in line with the study which was conducted by Kustanti $(2015,29)$ that most of the students in all grades have ever experienced disturbance from their friends. The most student who often gets the disturbance is students in elementary schools compared to junior and senior high schools or colleges.

Based on the human developmental stage, the aggressive behavior will reach to highest during the age between 2-4 years, then along with the time, it tends to be decreased (Tremblay \& Nagin, see Rahman 2013, 210). Aggression which is physical (physical aggression) on children is also affected by the quality of interaction with their friends. The existence of bullying behavior occurred in class has an effect on the quality of interpersonal relationship either with teachers or other students. Ormrod (2008, 213)disclosed that the quality of the relationship between teachers and students is one of the most important factors affecting emotional health, motivation, and student learning during in school. When students have positive relationship and support from their teachers, they will have higher self-efficacy and higher 
intrinsic motivation to study, besides their learning will be more self-regulated, they will tend to less naughty, and have higher achievement.

Negative behavior towards individual adjustment on surroundings is a result of individual learning process along with his life. A baby born in the world does not bring tendency of certain behavior towards nearby objects. There are some possibilities of this negative perception formation, such as viewed from the theory of social learning. According to Bandura (Hergenhahn and Olson 1997, 329), the tendency of having behavior is formed because of observing others. Through observing a model of someone behavior, he can create their behavior and show the same behavior as their attitude. The finding of this study obtained $42,5 \%$ of the respondents had a problem in adjustment related to their attitude towards their father and $10 \%$ of them had adjustment problem which was heavy enough related to their mother. A figure of parents they faced in their home was perceived less good so that this would direct them to certain behaviors when they were outside of their home, such as in school.

Bullying behavior which becomes aggressive action conducted repeatedly is a behavior against to Islamic values. The Quran stated some terms which direct to the definition of aggression (Rahman 2013, 199). There are 12 verses related to the word enmity (i'tada ya'tadi). There are 39 verses related to ruthlessness (dzalama, yadzlimu), there are 24 verses related to murder (qatala, yaqtulu), there are 39 verses related to the destructive action (fasada-yafsudu or 'asyiya-ya'syau). All in all, it also has 39 verses about scolding (istabzaa yastahziu).

The implementation of Islamic values in learning in schools should become a predictor of low bad behavior on students. However, based the finding on this study, it is found that bullying cases are still high. Besides, it is also found a fact about inter- 
personal relationship adjustment related to teachers and other students, and problem about their perception of school or their adjustment to school. Therefore, the implementation of Islamic value comprehensively and consistently is needed to decrease the students' negative behavior and appropriate intervention program must be conducted for preventing these problems worst.

\section{Conclusion}

Based on the findings, it can be concluded that students in Islamic school had a problem related to an adjustment in an interpersonal relationship, adjustment on school, self-concept adjustment, and family adjustment. The most problem reported by them was adjustment related to family mainly parents. Adjustment problem in an interpersonal relationship in school was dominated by a relational problem with friends reaching to 25 $\%$ who had a problem related to bullying. Besides, there were $24,3 \%$ of them reported have a problem-related individual adjustment on a severe level so that they would not be able to solve their problem well without teachers or parents or professionals help.

\section{Bibliography}

Aeni, Ani Nur. 2014. "Pendidikan Karakter Untuk Siswa SD Dalam Perspektif Islam.” Mimbar Sekolah Dasar 1: 50-58.

Ayu, Ida, Surya Dwipayanti, Dan Komang, and Rahayu Indrawati. 2014. "Hubungan Antara Tindakan Bullying Dengan Prestasi Belajar Anak Korban Bullying Pada Tingkat Sekolah Dasar." Jurnal Psikologi Udayana Program Studi Psikologi 1 (2): 251-60.

Bottiani, Jessika H, Catherine P Bradshaw, and Tamar Mendelson. 2016. "Journal of Educational Psychology A Multilevel Examination of Racial Disparities in High School 
Discipline : Adjustment Problems." Journal of Educational Psychology, 1-14.

Espelage, Dorothy L., Kris Bosworth, and Thomas R. Simon. 2000. "Examining the Social Context of Bullying Behaviors in Early Adolescence." Journal of Counseling \& Development 78 (3). Blackwell Publishing Ltd: 326-33. doi:10.1002/j.1556-6676.2000.tb01914.x.

Gerungan, W A. 2004. Psikologi Sosial. Bandung: Refika Aditama.

Glew, Gwen M., Ming-Yu Fan, Wayne Katon, Frederick P. Rivara, and Mary A. Kernic. 2005. "Bullying, Psychosocial Adjustment, and Academic Performance in Elementary School." Archives of Pediatrics \& Adolescent Medicine 159 (11): 1026-31. doi:10.1001/archpedi.159.11.1026.

Goddard, Connie. 2007. "Cyber World Bullying, Education Digest: Essential Readings Condensed for Quick Review, 2008-Mar." Illinois School Board Journal 75: 13-20.

Hergenhahn, B. R., and Matthew H. Olson. 1997. An Introduction to Theories of Learning. New Jersey: Prentice Hall International Inc.

Hunter, Simon C., James M. E. Boyle, and David. Warden. 2007. "Perceptions and Correlates of Peer-Victimization and Bullying." British Journal of Educational Psychology 77 (4). Blackwell Publishing Ltd: 797-810. doi:10.1348/000709906X171046.

Kustanti, Erin Ratna. 2015. "Gambaran Bullying Pada Pelajar Di Kota Semarang.” Jurnal Psikologi Undip 14 (1): 29-39.

O’Moore, Mona, and Stephen James Minton. 2004. Dealing with Bullying in Schools: A Training Manual for Teachers, 
Parents and Other Professionals. London: Paul Chapman Publishing. doi:10.4135/9781446211878.

Ormrod, Jeanne Ellis. 2008. Psikologi Pendidikan: Membantu Siswa Tumbuh Dan Berkembang. Jakarta: Erlangga.

Rahman, Agus Abdul. 2013. Psikologi Sosial: Integrasi Pengetahuan Wabyu Dan Pengetahuan Empirik. Jakarta: Raja Grafindo Persada.

Raju, M.V.R., and T. Khaja Rahamtulla. 2007. "Adjustment Problems among School Students." Journal of the Indian Academy of Applied Psychology 33 (1): 73-79.

Septrina, Mega Ayu, Cheryl Jocelyn Liow, Febrina Nur Sulistiyawati, and Inge Andriani. 2009. "Hubungan Tindakan Bullying Di Sekolah Dengan Self Esteem Siswa." In PESAT (Psikologi, Ekonomi, Sastra, Arsitektur, \& Sipil). Vol. 3. Jakarta: Universitas Gunadarma.

Sharp, Sonia, and Peter K. Smith. 2003. "Understanding Bullying." In Tackling Bullying in Your School: A Practical Handbook for Teachers. New York: Taylor \& Francis.

Simons-Morton, B. G., Aria Davis Crump, Denise L. Haynie, and Keith E. Saylor. 1999. "Studentschool Bonding and Adolescent Problem Behavior." Health Education Research 14 (1). Oxford University Press: 99-107. doi:10.1093/ her/14.1.99.

Siswanto. 2007. Kesehatan Mental: Konsep, Cakupan Dan Perkembangannya. Yogyakarta: Andi.

Siswati, and Costrie Ganes Widayanti. 2009. "Fenomena Bullying Di Sekolah Dasar Negeri Di Semarang: Sebuah Studi Deskriptif.” Jurnal Psikologi Undip 5 (2): 25-34. 


\section{ERNI AGUSTINA SETIOWATI}

Wenar, Charles, and Patricia Kerig. 2000. Developmental Psychopathology: From Infancy Through Adolescence. Boston: McGraw Hill. 